\title{
Overpressure Prediction In The North-West Niger Delta, Using Porosity Data
}

\author{
Etim D. Uko ${ }^{1}$, Juliet .E. Emudianughe ${ }^{2}$, I. Tamunobereton-ari \\ ${ }^{I}$ Department of Physics, Rivers State University of Science and Technology, P. M. B. 5080, Port Harcourt, \\ Rivers State, Nigeria $;{ }^{2}$ Federal University of petroleum Resources, Effurun, Delta State, Nigeria.
}

\begin{abstract}
Overpressure prediction in the North West of Niger Delta, using porosity data was carried out to safeguard hazards associated with drilling accident due to blowout. In the absence of seismic data to predict overpressure, porosity-dependent parameters and acoustic impedance could be used to predict the tops of overpressured zones in the area of study in the Niger Delta. Overpressure prediction is vital for safe and economic drilling. Composite logs were used to obtain the required data by digitizing the logs and deduction using the appropriate relationships. The findings from the study show that porosity decreases with depth, with overpressure zone detected at about $3500 \mathrm{~m}$ depth due to porosity deviation from normal trend. Pressure gradient in the upper normal pressure of the field is determined to be 0.989 psifft, this implies that within the established normal pressure gradient of $0.71-1.1 \mathrm{psi} f \mathrm{ft}$ in the Niger Delta. Formation overpressure gradient is determined to be $1.40 \mathrm{psi} / f t$. The overpressure zone coincides within the high shale-to-sand ratio of Agbada under compacted Formation. The identification of the tops of overpressure zones in any formation penetrated by a borehole enhances the use of normal drilling techniques of the borehole. This also reduces the cost of drilling the entire well as the special drilling technique will be applied only in the overpressure zones. This finding can aid in the prevention of drilling accident and resource wastage in exploration activities.
\end{abstract}

Key words: Porosity, acoustic velocity, compaction, lithology, overpressure, sedimentary basin.

\section{Introduction}

In petroleum exploration, the consequences of overpressures can be desirable in the sense that they encourage hydrocarbon migration. They can also reinforce the efficiency of the seal and thus protect the accumulation or can even have been at the origin of the structure through clay diapirism (Mouchet and Mitchell, 1989). Sometimes the impacts of overpressures are undesirable since they are often unpredictable and unquantifiable ahead of drilling. Exploration drilling may sustain heavy losses in both human and financial terms because of incomplete knowledge of formation pressure (Harkins and Baugher, 1969). Prediction of overpressure before drilling is critical at several stages in the exploration and development processes. In the exploration phase, it can assist in assessing the seal effectiveness and in mapping hydrocarbon migration pathways. It can also assist in the analysis of trap configurations and basin geometry, and provide calibration for basin modelling. In the drilling phase, an accurate pore-pressure prediction can be vital for safe and economic drilling (Dutta, 2002; Nfor, 2011).

Several authors have used different methods to determine overpressure zones in the Niger Delta. Owolabi et al (1990) used resistivity logs, Osinowo et al (2007) used interval transit time, Omolaiye et al (2009) used seismic data. Some of the other methods appplied include rate of penetration, (Jorden and Orval, 1964; Combs, 1968), temperature was also applied by Jones (1978), and shale density and velocity analysis by Satinder and Huffman (2006). This paper uses interval transit-time porosity and acoustic impedance to establish top of overpressure.

In the Niger Delta basin, where petroleum exploration has been continuing since the 1950s, it becomes necessary to assess overpressure zones in the basin, which is one of the hydraulic properties of rocks.

\section{Causes and Effects of Overpressure}

In the world's sedimentary basins, overpressures are associated with permeability barriers, tectonics, shale diagenesis, basin structure, and undercompaction among other factors (Hiller, 1991). In the Niger Delta basin, the very rapid deposition of Akata shales on the basement top has a sealing effect on the pores of shales. The sealing effect ceases the vertical flow of water and fluids cannot migrate freely. This causes undercompaction of the formations and abnormal high pressures are created (Bruce, 1973). The sealing effect can also be created as undercompacted and buoyant Akata shales below upheave into the overlying Agbada formation as demonstrated in Figure 3 (Weber and Daukuru, 1975; Whiteman, 1982). 


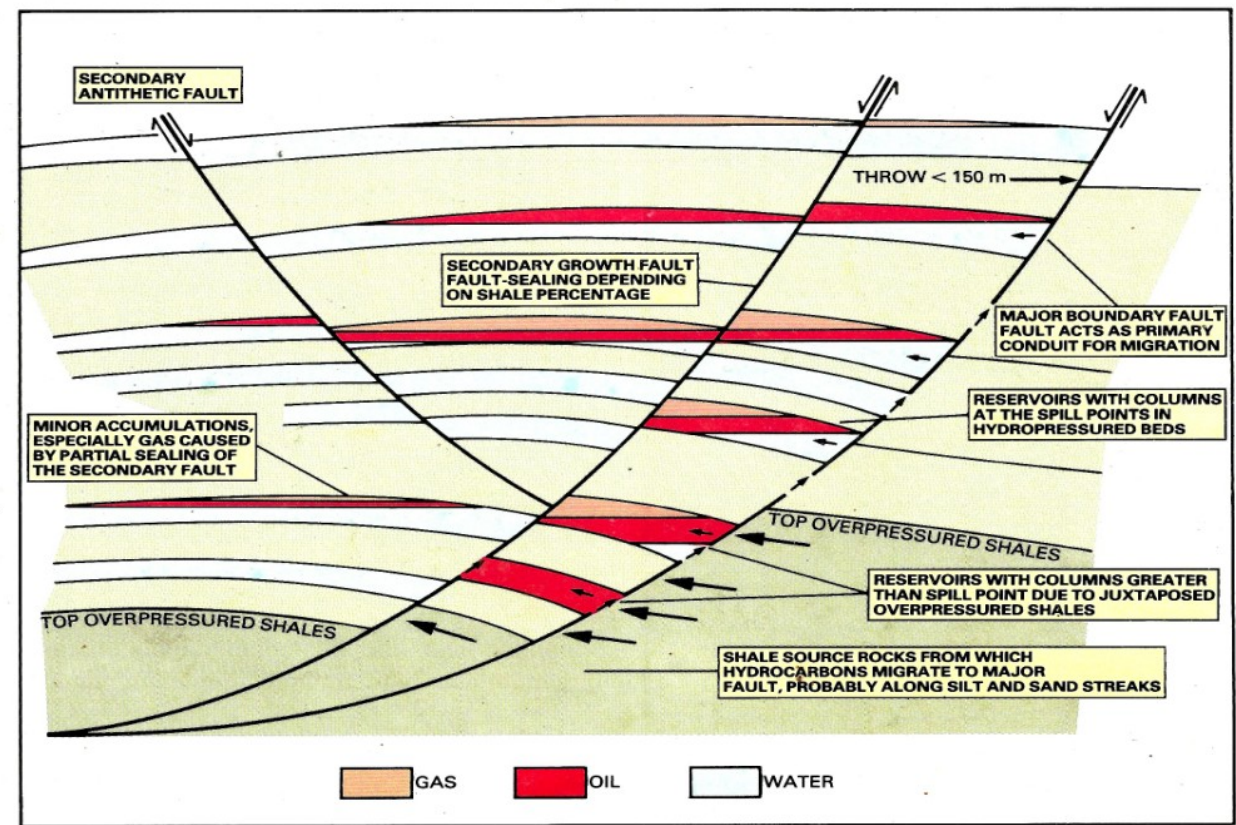

Fig. 3: Representation of overpressure communication in the Niger Delta by Weber and Daukuru, 1975, Whiteman, 1982.

\section{GEOLOGY OF NIGER DELTA, NIGERIA}

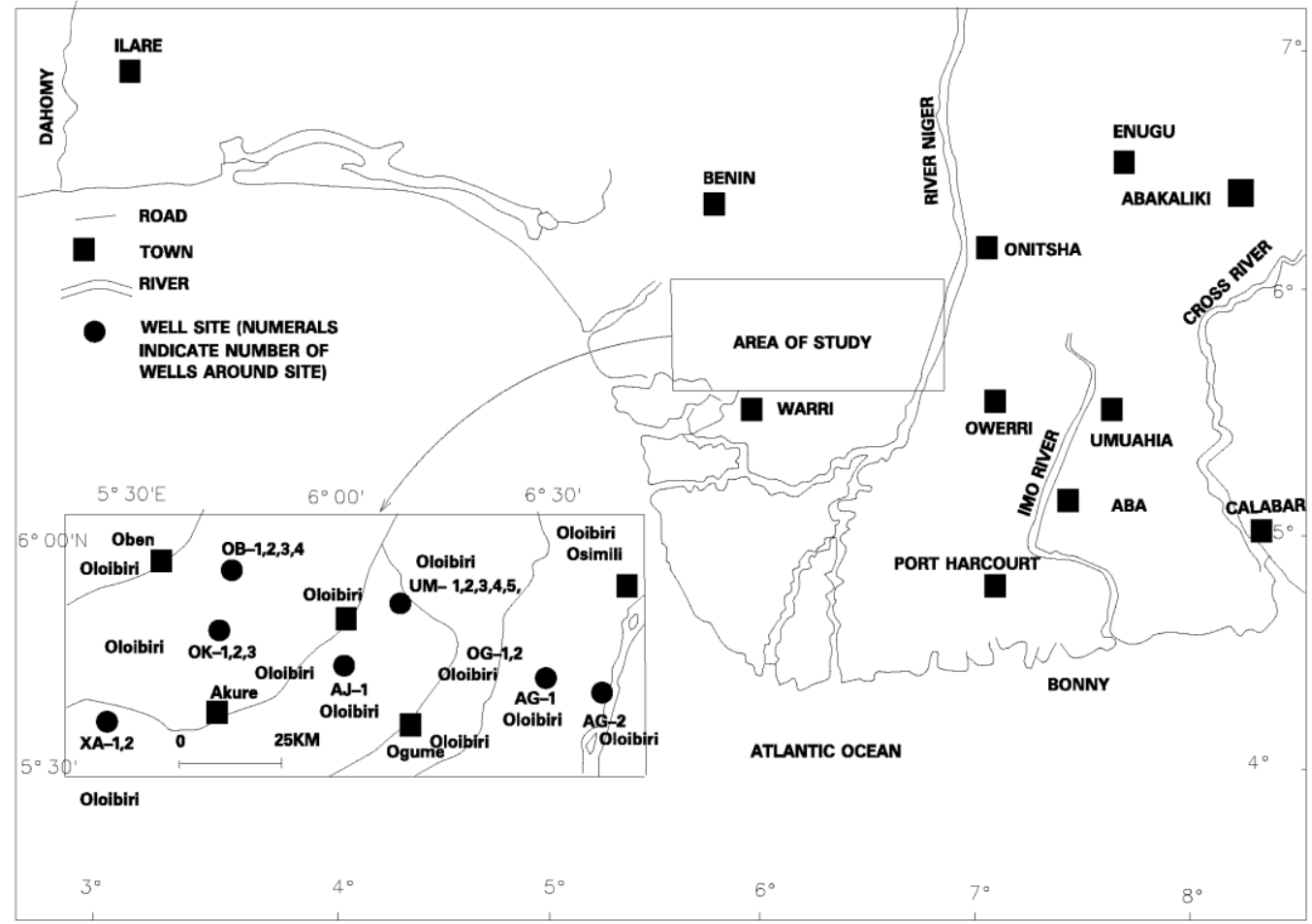

Fig. 1: Map of southern Nigeria showing the Niger delta region and the study area (Short and Stauble 1967)

The Niger Delta is situated at the West African margin of the Gulf of Guinea (Fig. 1). The stratigraphic sequence of the Niger Delta basin has been described by Short and Stauble (1967), Ofoegbu (1985), Uko et al. (1992). The Delta is composed of three major structural Formations: Akata, Agbada and Benin Formations (Fig. 2). 


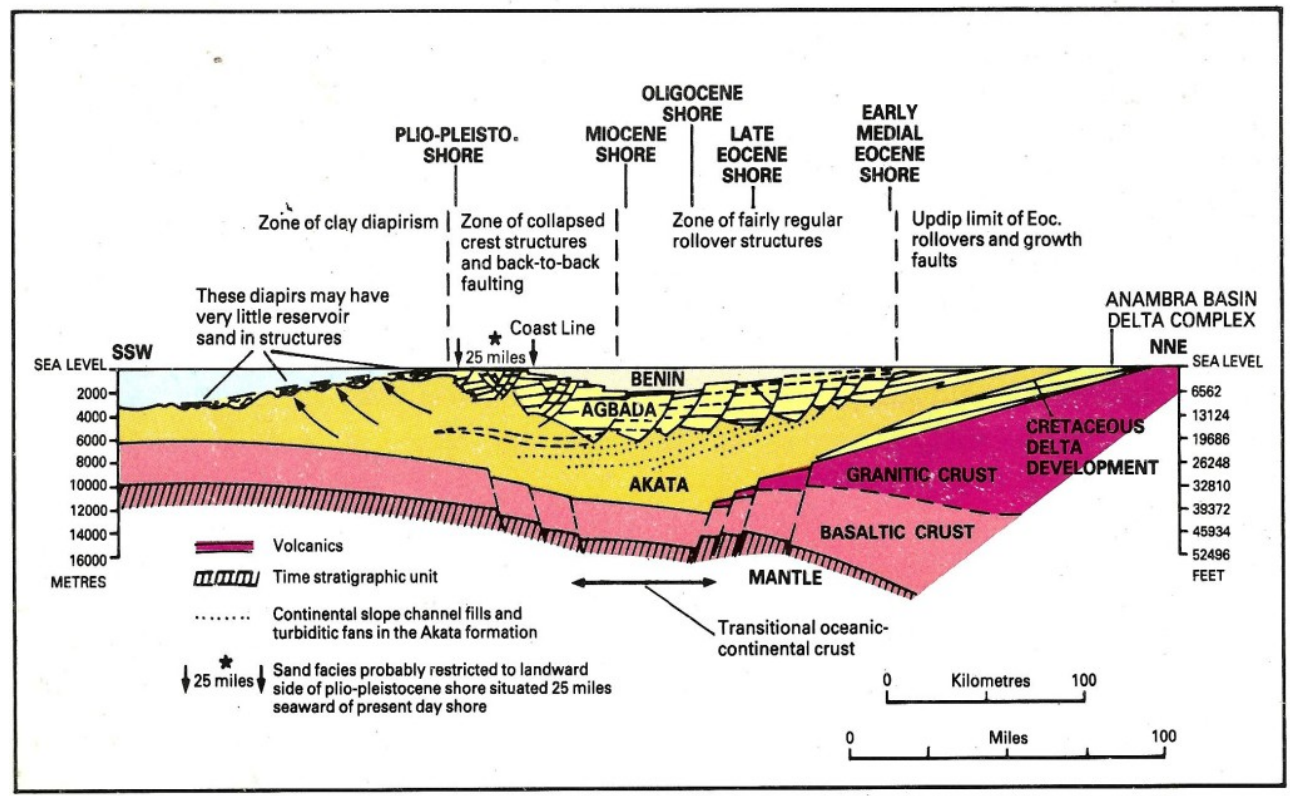

Fig. 2: Structural section of the Niger Delta Complex showing Benin, Agbada and Akata formations (Short and Stauble, 1967)

The Benin Formation is the upper alluvial coastal plain depositional environment of the Niger Delta Complex. It extends from the west Niger Delta across the entire Niger Delta area and to the south beyond the present coastline. The formation was deposited in a continental fluviatile environment and composed almost entirely of non-marine sandstone. It consists of coarse-grained sandstones, gravel lignite streaks and wood fragments with minor intercalation of shales. Benin Formation is of Miocene to younger age and has a variable thickness that exceeds $1820 \mathrm{~m}$. In the subsurface, it is of Oligocene age in the north becoming progressively younger southwards but ranges from Miocene to Recent as generally accepted. Very little hydrocarbon accumulation has been associated with this formation (Short and Stauble, 1967).

The Agbada Formation underlies the Benin Formation. It was laid down in paralic brackish to marine fluviatile, coastal environments. It is made up mainly of alternating sandstone, silt and shale. The sandstones are poorly sorted, rounded to sub-rounded, slightly consolidated but majority are unconsolidated. The sandstones grade into shale in the lower part of the formation. Agbada Formation ranges in age from Eocene in the north to Pliocene in the south. The sandy parts of the formation are known to constitute the main hydrocarbon reservoirs of the delta oil fields and the shales constitute seals to the reservoirs. The thickness of the formation reaches a maximum of about $4500 \mathrm{~m}$ (Short and Stauble, 1967).

The Akata Formation is the lowest unit of the Niger Delta complex. It is composed of mainly shale with sandstones and siltstones locally interbedded. The Formation becomes shalier with depth. It was deposited in a marine environment and has a thickness, which may reach $7000 \mathrm{~m}$ in the central part of the delta. The Akata Formation outcrops offshore in diapirs along the continental slope, and onshore in the north east, where they are called Imo Shale. The age of the Akata Formation ranges from Eocene to Recent (Short and Stauble, 1967).

\section{Materials And Methods}

In this paper, critical investigation was carried out on 19 closely-spaced petroleum wells-logs. The data obtained from these wells were used to estimate parameters such as porosity, velocity, acoustic impedance, overburden pressure, and lithologies.

\section{Lithology Estimation}

Gamma-ray log (Fig. 4) was used to delineate the lithologies at the pre-determined depth intervals. The American Petroleum Institute (API) values ranges from sandstone line 0 to shale line 150 . As the signature of the log move towards the higher values, the formation becomes more shaly. The delineation approach enabled us to estimate and establish the lithological sequence of the formation of the study area. Table 1 shows sand percentages at various depths, while Figure 5 is a cross plot of depth-sand percentages.

\section{Porosity estimation}

The Sonic logs, (Fig.4), were digitized to obtain transit time with which porosity is being computed using the relationship established by Schlumberger (1985): 


$$
\phi_{\text {sonic }}=0.625\left(1-\frac{\Delta t_{m a}}{\Delta t}\right)
$$

where $\Delta \mathrm{t}_{\mathrm{ma}}$ is the transit time of the matrix material $(\mu \mathrm{s} / \mathrm{ft})$, and $\Delta \mathrm{t}=$ reading on the Sonic $\log (\mu \mathrm{s} / \mathrm{ft})$. The interval transit time values were picked from the sonic log with depth. The reciprocal of the transit time gives the transit velocity. Porosity is treated as a function of lithology and depth, ranging from $5 \%$ for shales at a depth of about $4250 \mathrm{~m}$ and $51 \%$ for surface sandstones.

\section{Acoustic velocity and impedance estimation}

Acoustic velocity, $\mathrm{Vp}$, was computed by taking the reciprocal of the transit time, and is given as:

$$
V_{P}=\frac{1}{\Delta t}
$$

Bulk density with depth was estimated using Density log. Compressional acoustic impedance, AI, is a product of bulk density and acoustic velocity, and is given as:

$$
\mathrm{AI}=\mathrm{V}_{\mathrm{p} \rho} \rho
$$

measured in $\mathrm{gcm}^{-2} \mathrm{~s}^{-1}$, where $\mathrm{V}_{\mathrm{p}}$ is velocity in $\mathrm{cms}^{-1}$, and $\rho$ is density in $\mathrm{gcm}^{-3}$.

\section{Pore overburden pressure}

This parameter was deduced using the relation:

$$
\mathrm{P}=\mathrm{hg} \rho
$$

Where $\mathrm{P}=$ overburden pressure, $\mathrm{h}=$ depth of burial of rock, $\rho=$ density of rock, $\mathrm{g}=$ acceleration due to gravity.

\section{Results and Discussion}

Normal and abnormal pore pressure zones were delineated based on the principle of normal and deviation from normal porosity trends. The transition between the two trends signifies the top of the overpressure zone. The accuracy of the predicted overpressure zone was confirmed from the computed densityderived acoustic impedance for shale-sandstone lithologies, Figure 6. The variation to the depth of the overpressure between the predicted and the observed values was less than $5 \mathrm{~m}$, with confidence of over $90 \%$. This depth conforms to the thick marine Agbada shales using composite log. Prediction of the top of the overpressure zone within the North-west of Niger Delta for potential wells will be total depth beyond $3300 \mathrm{~m}$ sub-sea for safer drilling programme.

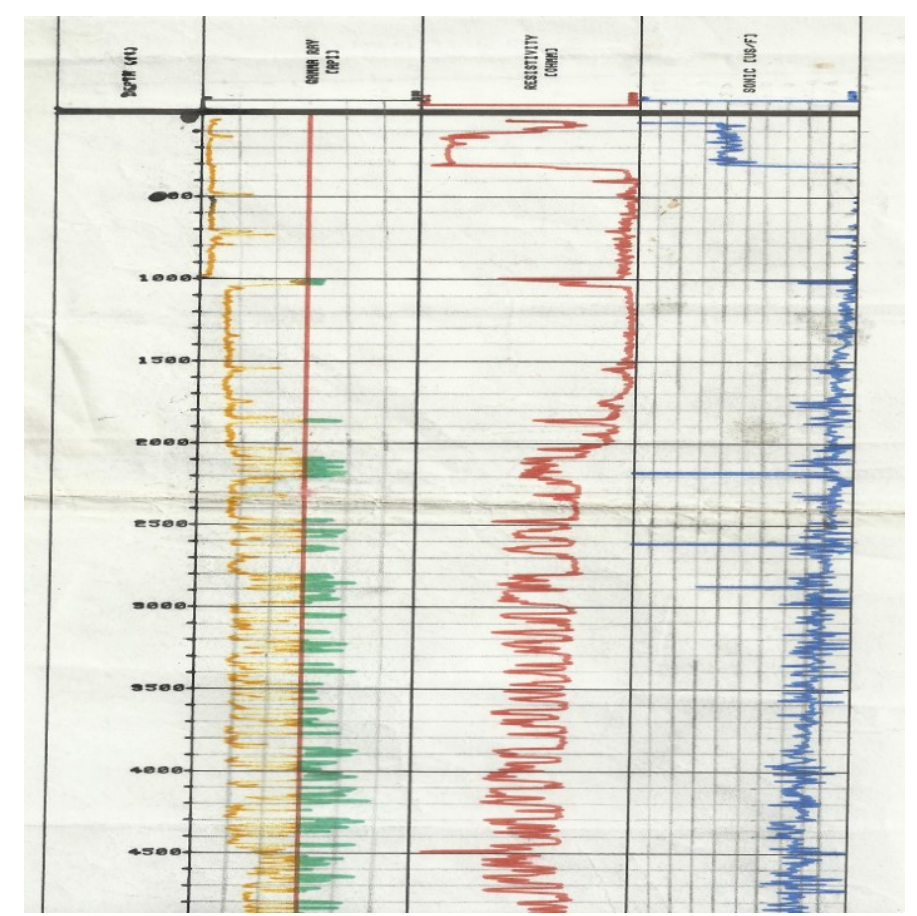

Fig. 4: Typical composite well Log for estimating sand ratio and transit travel time. 


\begin{tabular}{|c|c|c|c|c|c|c|c|}
\hline Depth (m) & \begin{tabular}{|c|} 
Sand volume \\
$(\%)$
\end{tabular} & $\left.\begin{array}{c}\text { Velocity }\left(\mathrm{Kms}^{-}\right. \\
1\end{array}\right)$ & Porosity (\%) & $\left.\begin{array}{c}\text { Density }\left(\mathrm{gcm}^{-}\right. \\
3\end{array}\right)$ & $\begin{array}{c}\text { Pore overburden } \\
\text { pressure (psi) }\end{array}$ & $\begin{array}{l}\text { Acoustic } \\
\text { impedance } \\
(\mathrm{g} / \mathrm{cm} . \mathrm{s})\end{array}$ & $\begin{array}{c}\text { Overburden pressure } \\
\text { gradient } \\
(\mathrm{psi} / \mathrm{ft})\end{array}$ \\
\hline 1408 & 90 & 8.33 & 34 & 2.01 & 4103.616 & 1674330 & 0.94425 \\
\hline 1415 & 90 & 8 & 35 & 2.05 & 4206.088 & 1640000 & 0.898189 \\
\hline 1454 & 90 & 7.94 & 35 & 1.95 & 4111.185 & 1548300 & 0.902795 \\
\hline 1484 & 90 & 9.52 & 29 & 1.96 & 4217.528 & 1865920 & 0.981099 \\
\hline 1524 & 90 & 8.33 & 34 & 2.13 & 4706.874 & 1774290 & 0.898189 \\
\hline 1609 & 90 & 8.33 & 34 & 1.95 & 4549.448 & 1624350 & 0.967281 \\
\hline 1655 & 65 & 9.09 & 31 & 2.1 & 5039.475 & 1908900 & 0.948856 \\
\hline 1695 & 80 & 9.52 & 29 & 2.06 & 5062.965 & 1961120 & 0.948856 \\
\hline 1771 & 85 & 10 & 28 & 2.06 & 5289.977 & 2060000 & 0.898189 \\
\hline 1865 & 85 & 9.52 & 29 & 1.95 & 5273.288 & 1856400 & 0.967281 \\
\hline 1871 & 85 & 10 & 28 & 2.1 & 5697.195 & 2100000 & 0.967281 \\
\hline 1978 & 85 & 9.09 & 31 & 2.1 & 6023.01 & 1908900 & 0.967281 \\
\hline 2063 & 90 & 10 & 28 & 2.1 & 6281.835 & 2100000 & 0.985705 \\
\hline 2100 & 80 & 10 & 28 & 2.14 & 6516.3 & 2140000 & 0.967281 \\
\hline 2106 & 85 & 10 & 28 & 2.1 & 6412.77 & 2100000 & 0.967281 \\
\hline 2195 & 85 & 10.53 & 26 & 2.1 & 6683.775 & 2211300 & 0.981099 \\
\hline 2298 & 85 & 10.53 & 26 & 2.13 & 7097.373 & 2242890 & 1.013342 \\
\hline 2341 & 85 & 10 & 28 & 2.2 & 7467.79 & 2200000 & 1.013342 \\
\hline 2377 & 85 & 11.76 & 22 & 2.2 & 7582.63 & 2587200 & 1.013342 \\
\hline 2429 & 85 & 10.53 & 26 & 2.2 & 7748.51 & 2316600 & 1.013342 \\
\hline 2463 & 85 & 10.87 & 25 & 2.2 & 7856.97 & 2391400 & 0.94425 \\
\hline 2499 & 90 & 11.11 & 24 & 2.05 & 7428.278 & 2277550 & 0.990311 \\
\hline 2609 & 90 & 11.11 & 24 & 2.15 & 8133.558 & 2388650 & 0.94425 \\
\hline 2643 & 65 & 11.76 & 22 & 2.05 & 7856.318 & 2410800 & 0.990311 \\
\hline 2744 & 80 & 11.76 & 22 & 2.15 & 8554.42 & 2528400 & 1.02716 \\
\hline 2886 & 65 & 11.76 & 22 & 2.23 & 9331.881 & 2622480 & 1.036372 \\
\hline 2896 & 65 & 11.36 & 23 & 2.25 & 9448.2 & 2556000 & 1.013342 \\
\hline 2972 & 75 & 11.9 & 21 & 2.2 & 9480.68 & 2618000 & 1.017948 \\
\hline 3091 & 75 & 12.05 & 21 & 2.21 & 9905.11 & 2663050 & 1.031767 \\
\hline 3141 & 80 & 12.5 & 19 & 2.24 & 10201.97 & 2800000 & 1.013342 \\
\hline 3163 & 50 & 12.5 & 19 & 2.2 & 10089.97 & 2750000 & 1.02716 \\
\hline 3222 & 60 & 12.82 & 18 & 2.23 & 10418.34 & 2858860 & 1.036372 \\
\hline 3253 & 55 & 12.5 & 19 & 2.25 & 10612.91 & 2812500 & 0.94425 \\
\hline 3301 & 65 & 12.5 & 19 & 2.05 & 9812.223 & 2562500 & 0.990311 \\
\hline 3324 & 90 & 11.76 & 22 & 2.15 & 10362.57 & 2528400 & 0.92122 \\
\hline 3383 & 95 & 9.52 & 29 & 2 & 9810.7 & 1904000 & 1.059403 \\
\hline 3414 & 95 & 13.51 & 16 & 2.3 & 11385.69 & 3107300 & 1.036373 \\
\hline 3447 & 95 & 13.7 & 15 & 2.25 & 11245.84 & 3082500 & 1.013342 \\
\hline 3453 & 90 & 12.82 & 18 & 2.2 & 11015.07 & 2820400 & 1.036373 \\
\hline 3475 & 90 & 12.82 & 18 & 2.25 & 11337.19 & 2884500 & 1.082434 \\
\hline 3466 & 80 & 13.16 & 17 & 2.35 & 11810.4 & 3092600 & 1.036372 \\
\hline 3505 & 80 & 13.16 & 17 & 2.25 & 11435.06 & 2961000 & 1.059403 \\
\hline 3517 & 80 & 11.36 & 23 & 2.3 & 11729.2 & 2612800 & 1.059403 \\
\hline 3566 & 80 & 13.7 & 15 & 2.3 & 11892.61 & 3151000 & 0.990312 \\
\hline
\end{tabular}


Overpressure Prediction In The North-West Niger Delta, Using Porosity Data

\begin{tabular}{|c|c|c|c|c|c|c|c|}
\hline 3574 & 65 & 12.82 & 18 & 2.15 & 11141.95 & 2756300 & 1.036372 \\
\hline 3597 & 65 & 13.7 & 15 & 2.25 & 11735.21 & 3082500 & 1.082433 \\
\hline 3603 & 60 & 13.33 & 16 & 2.35 & 12277.22 & 3132550 & 1.082434 \\
\hline 3634 & 50 & 11.11 & 24 & 2.35 & 12382.86 & 2610850 & 1.059403 \\
\hline 3671 & 55 & 14.29 & 13 & 2.3 & 12242.79 & 3286700 & 1.082433 \\
\hline 3695 & 65 & 13.7 & 15 & 2.35 & 12590.71 & 3219500 & 0.967281 \\
\hline 3709 & 60 & 13.89 & 14 & 2.1 & 11293.91 & 2916900 & 1.059403 \\
\hline 3749 & 75 & 11.11 & 24 & 2.3 & 12502.92 & 2555300 & 1.036372 \\
\hline 3789 & 75 & 12.5 & 19 & 2.25 & 12361.61 & 2812500 & 1.082434 \\
\hline 3810 & 75 & 10.53 & 26 & 2.35 & 12982.58 & 2474550 & 1.036373 \\
\hline 3822 & 75 & 10 & 28 & 2.25 & 12469.28 & 2250000 & 1.082433 \\
\hline 3848 & 75 & 11.11 & 24 & 2.35 & 13112.06 & 2610850 & 1.013342 \\
\hline 3862 & 75 & 12.82 & 18 & 2.2 & 12319.78 & 2820400 & 1.105464 \\
\hline 3871 & 80 & 10.31 & 27 & 2.4 & 13471.08 & 2474400 & 1.077827 \\
\hline 3894 & 90 & 10.53 & 26 & 2.34 & 13212.34 & 2464020 & 1.082433 \\
\hline 3904 & 50 & 10 & 28 & 2.35 & 13302.88 & 2350000 & 1.036373 \\
\hline 3923 & 75 & 11.11 & 24 & 2.25 & 12798.79 & 2499750 & 1.036372 \\
\hline 3928 & 75 & 10.53 & 26 & 2.25 & 12815.1 & 2369250 & 1.036372 \\
\hline 3936 & 75 & 10.53 & 26 & 2.25 & 12841.2 & 2369250 & 1.036373 \\
\hline 3951 & 75 & 12.5 & 19 & 2.25 & 12890.14 & 2812500 & 1.036373 \\
\hline 3962 & 75 & 10.2 & 27 & 2.25 & 12926.03 & 2295000 & 1.059403 \\
\hline 3984 & 85 & 10.31 & 27 & 2.3 & 13286.64 & 2371300 & 1.059403 \\
\hline 4001 & 85 & 9.43 & 29 & 2.3 & 13343.34 & 2168900 & 1.082434 \\
\hline 4022 & 85 & 9.52 & 29 & 2.35 & 13704.97 & 2237200 & 1.082434 \\
\hline 4033 & 85 & 10 & 28 & 2.35 & 13742.45 & 2350000 & 1.082434 \\
\hline
\end{tabular}

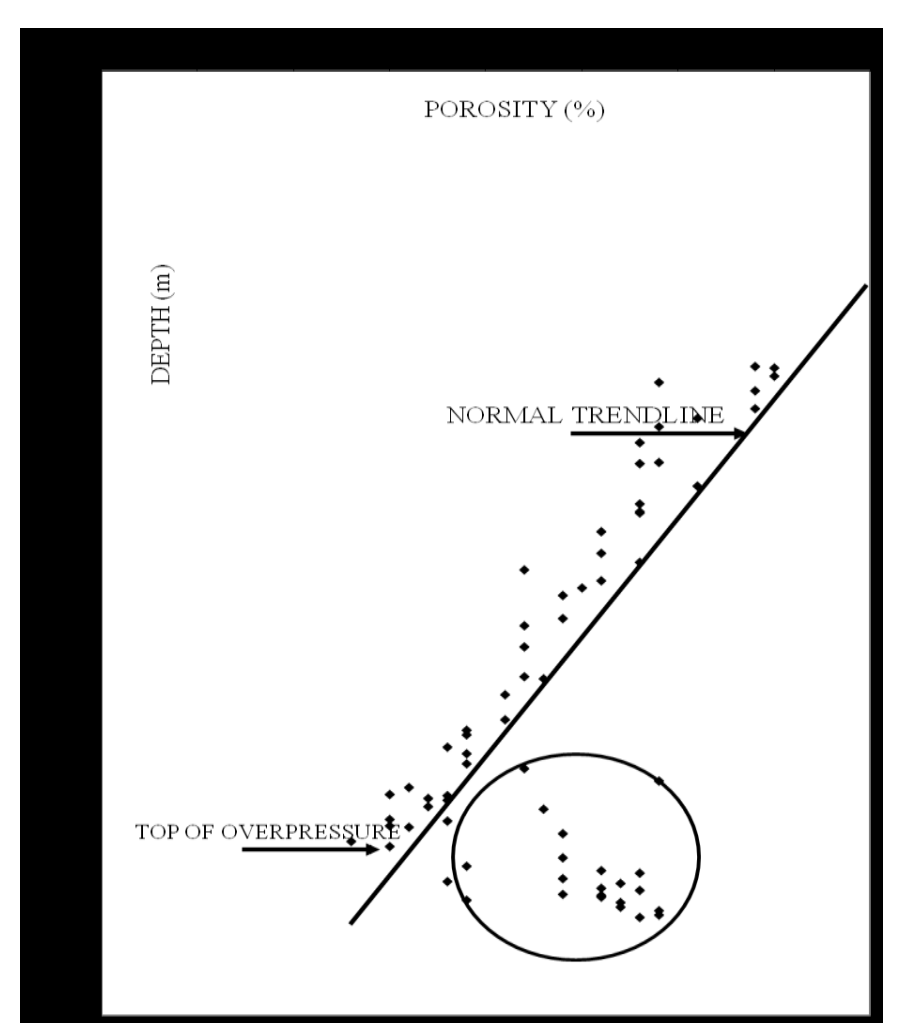

Fig. 5: Depth-porosity cross-plot 


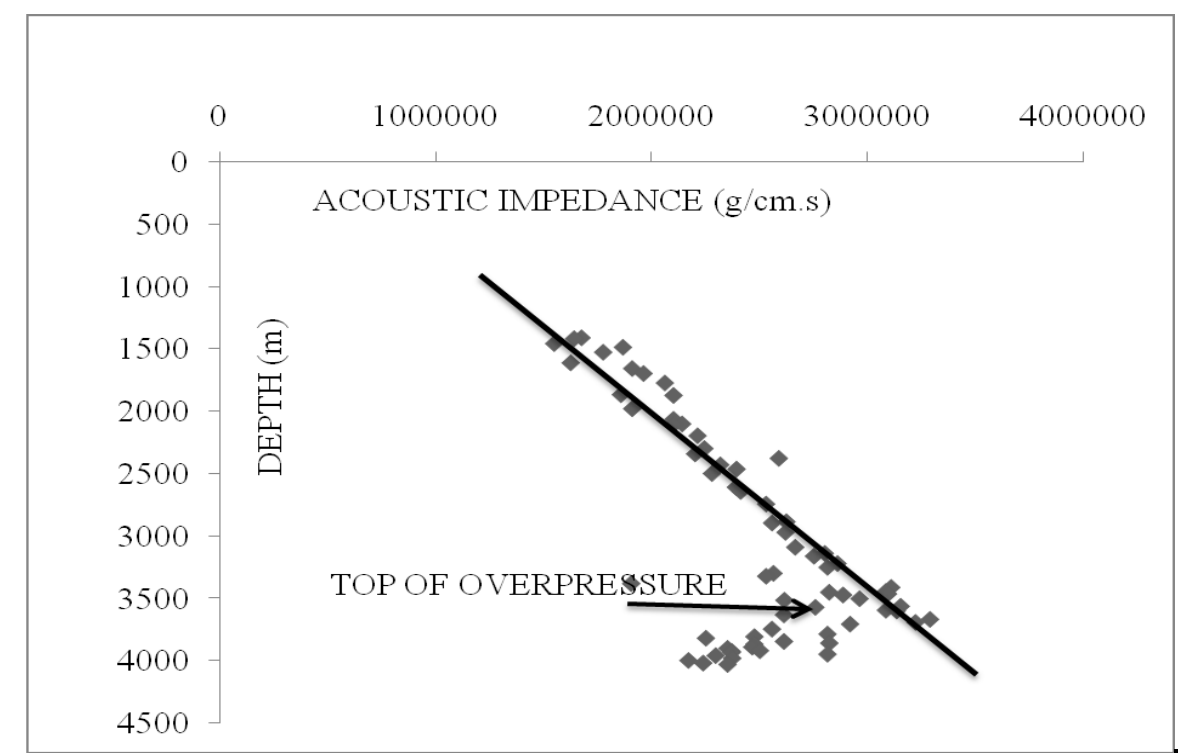

Fig. 6: Depth-Log Velocity cross-plot

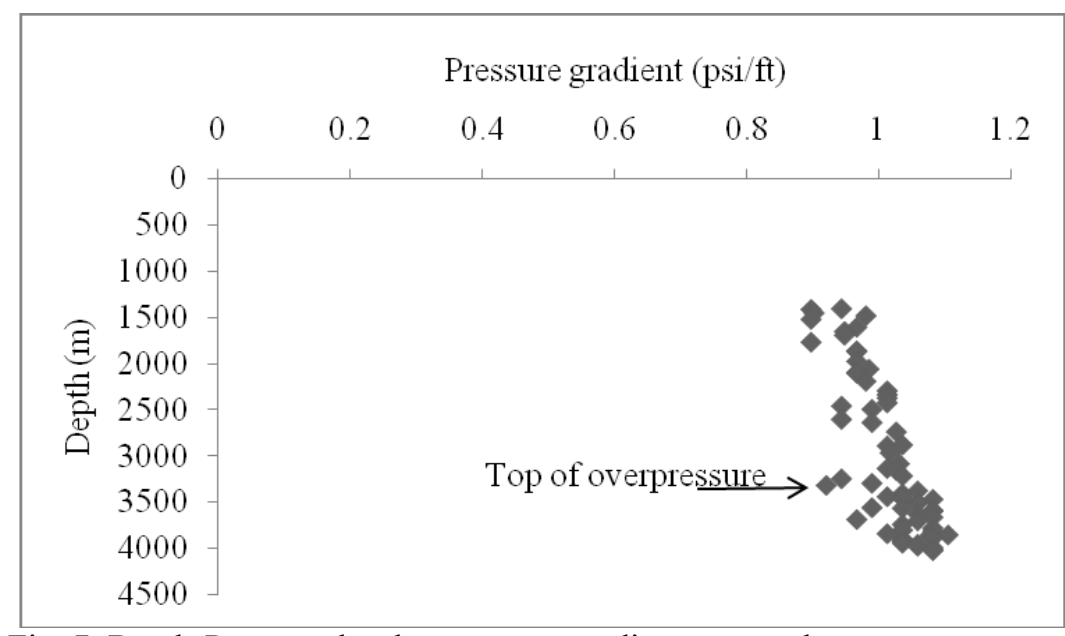

Fig. 7: Depth-Pore overburden pressure gradient- cross-plot

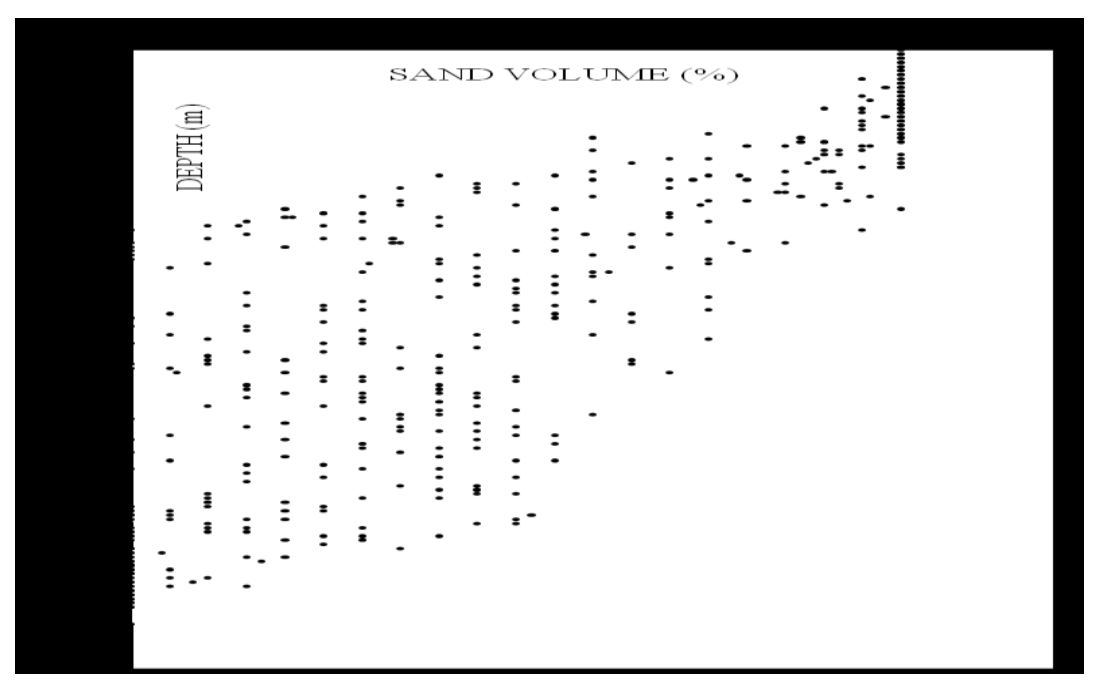

Fig 8 Depth-Sand volume cross plot 


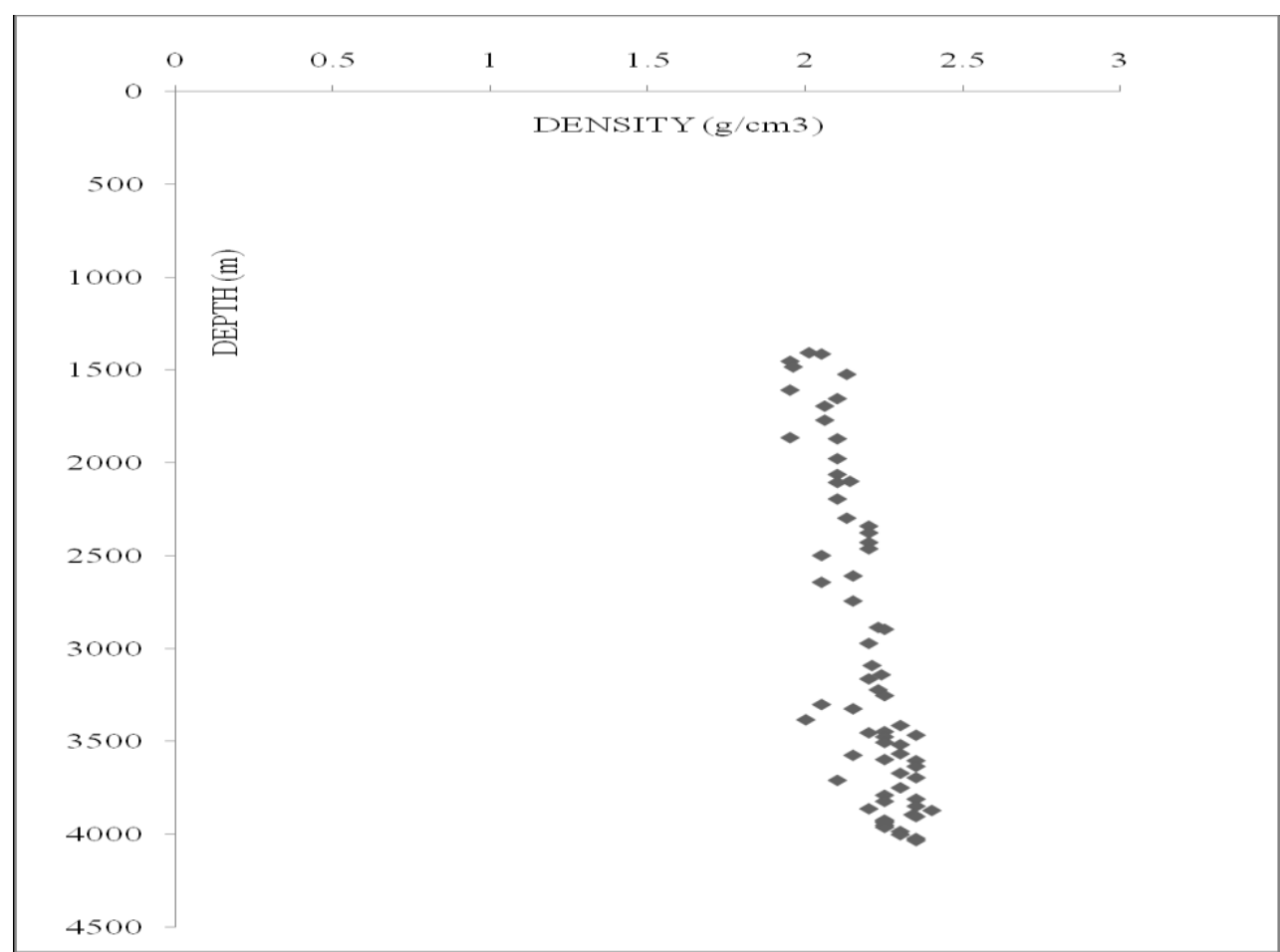

Fig. 9: Depth-density cross-plot

\section{Porosity}

Porosity values range between $9 \%$ at depth and $51 \%$ at the surface. The computed porosity is plotted against depth. Porosity decreases with depth.

The porosities were also plotted against depth on a semi log paper with porosity values on logarithmic scale and depth values on the linear scale. A line of best fit is drawn through the plotted points showing porosity-decreasewith-depth trend, in normal compaction (Fig. 5).

\section{Pressure gradient}

In normal pressure environments the plots of depth versus porosity on semi log paper show all data points falling along the line of normal compaction trend (Figures 5 - 7). This plot establishes both normal and abnormal compaction trend with the view to predict well abnormal geopressures. A sudden increase in porosity with depth implies the presence of overpressures (under compaction), Figures 5, 6 and 7 is due to an increase in porosity, implying the presence of overpressures (under compaction). Under normal compaction, porosity of rocks decrease with depth, but when overpressured (under compacted) layers are encountered, the trend is reversed in Figures 5,6 and 7. Abnormal formation pressures at a depth of between 3300 and $4000 \mathrm{~m}$ was observed in the area of study.

\section{Conclusion}

In conclusion, Porosity is controlled by depth of burial; Porosity increases below the top of undercompacted overpressured shaley Agbada formation at the depth of $3300 \mathrm{~m}$; Over pressure is encountered from about $3300 \mathrm{~m}$ which is an effective depth of concern as effective pressure at this depth is enormous to cause massive devastation if not accurately predicted drilling. Pressure gradient in the upper normal pressure of the field is determined to be $0.989 \mathrm{psi} / \mathrm{ft}$, this implies that within the established normal pressure gradient of 0.71 $1.1 \mathrm{psi} / \mathrm{ft}$ in the Niger Delta. Formation overpressure gradient is determined to be $1.40 \mathrm{psi} / \mathrm{ft}$. The overpressure zone coincides within the high shale-to-sand ratio of Agbada under compacted Formation. The identification of the tops of overpressure zones in any formation penetrated by a borehole enhances the use of normal drilling techniques of the borehole. This also reduces the cost of drilling the entire well as the special drilling technique will be applied only in the overpressure zones. This finding can aid in the prevention of drilling accident and resource wastage in exploration activities.

\section{Acknowledgements}

We are very grateful to Shell Petroleum Development Company of Nigeria for the data. 


\section{References}

[1]. Bruce, C. H. Pressured shale and related sediment deformation, mechanism for the development of regional contemporaneous faults, AAPG Bull. 1973,57, 878 - 886.

[2]. Dutta, N. Geopresure prediction using seismic data: current status and the road ahead, Geophysics, 2002, 67, No. 6, pp. 2012 - 2041.

[3]. Hiller, I., Origins of abnormal pressure. Baker Hughs INTEQ lecture for training clients and field service engineers, 1991 pp. 14.

[4]. Hottmann, C. E., Johnson R. K. Estimation of formation pressures from log-derived shale properties, J. Pet. Tech., 1965, Vol. 6, $717-722$.

[5]. Ofoegbu, C. O. A review of the geology of the Benue Trough, Nigeria, J. Afr. Earth Sci. 1985 Vol. 3, 283 - 291.

[6]. Omolaiye, G. E, Ojo. J. S, Oladapo. M. I. and Ayolabi, E.A. Overpressure prediction of the Efomeh field using synthetic data, onshore Niger Delta, Nigeria. Exploration Geophysics, 2011, 42 (1), 50 - 57.

[7]. Osinomo, O. O., Oladunjoye, M. A., and Olayinka, A. I. Overpressure prediction from seismic data: implications on drilling safety. American geophysical Union, Fall Meeting 2007, Abstract \#S23A-1113.

[8]. Owalabi, O. O., Okpobiri, G. A., Obomanu, I. A. Prediction of abnormal pressure in the Niger Delta using well logs. CIM/SPE International Technical Meeting, 1990, Calgary, Canada.

[9]. Jones, P. H. Problems of petroleum migration, America Association of Petroleum Geologists Bull. 1978 Vol. 10, 207 - 216.

[10]. Schlumberger, Well evaluation conference, Schlumberger Technical Services, Inc., 1985 Vol. 2, p. 113 - 124.

[11]. Short K. C. and Stauble, A. Outline of Geology of Niger Delta, America Association of Petroleum Geologists Bull. 1967 Vol. 51 , pp. $761-779$.

[12]. Uko, E. D, Ekine. A.S. J. O. Ebeniro. J.O, Ofoegbu. C.O, Weathering structure of east central Niger Delta, Nigeria, Geophysics, $199257(9), 1228-1233$.

[13]. Weber, K. J., Daukuru. E.M, Petroleum geological aspects of the Niger Delta, Journal of Mining Geology, 1975 Vol. 12 , p. 9 - 12.

[14]. Whiteman, A. Nigeria: Its petroleum geology, resource and potential, London 1982 